УДК 615.014.2:615.454.1:615.262.1:616.72

DOI: 10.15587/2519-4852.2018.151447

\title{
STUDIES ON THE DESIGN OF A COMPOSITION OF GEL FOR THE TREATMENT OF INFLAMMATORY DISEASES OF THE JOINTS
}

\author{
(C) L. Vyshnevska, O. Strilets, V. Postoy
}

The aim: the aim of our work was to experimentally substantiate the effectiveness of antimicrobial preservatives in the design of the composition of the combined gel for the treatment of acute and chronic inflammation of the joints.

Methods: biological pharmacopoeial method of research was used (research of the effectiveness of antimicrobial preservatives).

Results. All drugs must meet the requirements of regulatory documents on indicators "Microbiological purity." To ensure the microbiological stability of the preparations, it is necessary to eliminate the factors associated with microbial contamination, therefore we carried out experimental studies on the choice of preservative and its concentration for the developed gel. According to the results of experimental studies on the effectiveness of antimicrobial preservatives in gel samples, the following data were obtained. Samples of the studied gel with sodium preservatives benzoate $0.5 \%$ and nipagin $0.2 \%$ meet the criterion " $A$ " according to the requirements of SPHU for drugs for skin application. But, according to research results, the antimicrobial efficacy of the gel with the preservative nipagin $0.2 \%$ was slightly higher (lg reduction in the number of viable Staphylococcus aureus ATCC 6538 cells was 3.32 and 4.81; Pseudomonas aeruginosa ATCC 9027 - 3.28 and 4.66 ; Candida albicans ATCC 885-653 - 3.50 and 4.09; Aspergillus brasiliensis ATCC 16404 - 3.10 and 4.00 (2 and 7 days, respectively) and the spectrum of antimicrobial action is wider, which will contribute to the quality of the rotated gel also during storage. Therefore, for further research, we will use nipagin $0.2 \%$ as a preservative.

Conclusions: The expediency of using nipagin $0.2 \%$ as a part of a combined gel for the treatment of acute and chronic joint inflammation has been theoretically proved and experimentally proved

Keywords: combined gel, composition, preservatives, antimicrobial activity, nipagin, technology, inflammation of the joints

\section{Introduction}

Despite the fact that several dozen innovative and hundreds of generic drugs appear on the global pharmaceutical market each year, medicinal plant raw material (MPRM) continue to account for a significant proportion. Ukraine differs from a number of countries not only with favourable climatic conditions and a large variety of flora, but also a rich history of manufacturing MPRM. Today in the world there are about 12 thousand plants that have healing properties and are used in both traditional and folk medicine. In this case, medicinal plants are often combined with other methods of treatment $[1,2]$.

Currently, according to the Ministry of Health, the prevalence of rheumatoid arthritis is about 116492 patients, including 52,000 people of working age. Inflammatory of joints affects the national economy, lead to significant costs of treatment and reduce the quality of life of the patients. Loss of disability and the growth of disability are the most important socio-economic consequences of them [3, 4].

Therefore, and taking into account that in the treatment of chronic diseases of the joints, the pharmacotherapy is long, it would be advisable to use medicinal preparations on the basis of medicinal plant material $[5,6]$.

Thus, when designing the composition of the drug - a combined gel for the treatment of acute and chronic joint diseases, the choice of preservative and the determination of its concentration are relevant research.
2. Formulation of the problem in a general way, the relevance of the theme and its connection with important scientific and practical issues

In order to ensure the microbiological stability of new dosage forms that meet the requirements of normative documents according to the indicator "Microbiological purity", maximum elimination of the factors related to microbial contamination is necessary, therefore it is expedient to conduct experimental research on the choice of preservative and its concentration for the developed gel. It is precisely the definition of the optimal concentration of preservatives in the composition of medicinal products, which is one of the approaches to solving the problem of microbiological purity and stability of the drugs $[7,8]$.

3. Analysis of recent studies and publications in which a solution of the problem are described and to which the author refers

When creating new drugs, one of the main tasks is a long shelf life, that is, minimizing the disadvantages inherent in the medical form - instability when stored and usage after opening the package. In order to solve this problem, auxiliary substances are used, in particular antimicrobial preservatives. In pharmacy preservatives are used nipagine, nipazole, bronopol, benzoic acid, potassium sorbate, sodium benzoate, ethanol and combinations of various preservatives. The biological method of SPHU conducts experimental studies of developed gels samples with different preservatives and their con- 
centrations to substantiate the choice of the most effective in each particular drug $[9,10]$.

\section{The field of research considering the general problem, which is described in the article \\ The combined composition of gel for the treat-} ment of acute and chronic diseases of the joints, where active ingredients are biologically active substances of the original composition of medicinal plant raw material was previously designed and developed, but the problem of its stabilization for the purpose of long storage period remained unsolved.

\section{Formulation of goals (tasks) of article}

The aim of the work was to study the effectiveness of antimicrobial preservatives in the process of developing the composition of a complex combined gel for the treatment of acute and chronic diseases of the joints.

6. Presentation of the main research material (methods and objects) with the justification of the results

To conduct the research on the effectiveness of the antimicrobial action of preservatives, we have manufactured experimental samples of sodium gel with benzoate and nipagin at various concentrations, as well as without preservative.

In the studies, a method for evaluating the effectiveness of antimicrobial preservatives, as described in SPHU 2.0 (Section 5.1.3, pp. 773-775) was used. When conducting research data, samples of the finished dosage forms of gels with different preservatives in the original package were inoculated with different cultures of test microorganisms. The non-coated samples were stored in a dark place at a temperature of $20-25{ }^{\circ} \mathrm{C}$ for 28 days. In the study of medicinal products for the application on the skin, the determination of the number of viable microorganisms after inoculation is carried out immediately after the preparation of the form and after 2 , 7,14 and 28 days of storage [7, 8].

According to the requirements of SPHU, as cultures of test microorganisms used Staphylococcus aureus ATCC 6538, Pseudomonas aeruginosa ATCC 9027, Candida albicans ATCC 885-653, Aspergillus brasiliensis ATCC 16404. As a nutrient medium, dense soy-casein medium was used as a nutrient medium, and fungi Saburo-dextrose medium without the addition of antibiotics. Prior to conducting research, experiments were carried out to match the growth properties of nutrient media (the number of colonies grown during the cropping of the corresponding number of microorganisms). The obtained results showed the correspondence of all cultures of microorganisms (Staphylococcus aureus ATCC 6538, Pseudomonas aeruginosa ATCC 9027 and Candida albicans ATCC 885-653, Aspergillus brasiliensis ATCC 16404) to the taxonomic designation of the strain.
For inoculation of gel specimens with microorganism cultures, suspensions of bacteria and fungi were prepared using a sterile suspension solution containing $9.0 \mathrm{~g} / \mathrm{L}$ of sodium chloride $\mathrm{P}$ (in the preparation of a culture suspension of Aspergillus brasiliensis, a sterile suspension solution containing $9.0 \mathrm{~g} / \mathrm{L}$ sodium chloride $\mathrm{P}$ and $0.5 \mathrm{~g} / \mathrm{L}$ polysorbate- $80 \mathrm{P}$ ). The microbial load of the cells was adjusted to 108 cells per $\mathrm{ml}$ of suspension.

From each culture slurry, immediately after cooking, a sample was taken and the amount of colony forming units (CFUs) in $1 \mathrm{ml}$ was determined by direct seeding on Petri dishes on dense nutrient media used for initial growth of test cultures.

Each gel sample was subjected to suspension containing a test microorganism with a load of $108 \mathrm{CFU} /$ $\mathrm{ml}$. In the sample itself, the microbial load should be from $105 \mathrm{CFU} / \mathrm{ml}$ to $106 \mathrm{CFU} / \mathrm{ml}$

Specimens without preservatives have also been inoculated with cultures of Staphylococcus aureus ATCC 6538, Pseudomonas aeruginosa ATCC 9027, Candida albicans ATCC 885-653, Aspergillus brasiliensis ATCC 16404 and stored for a while. For the 5th day of storage, all specimens were characterized by the growth of microorganisms, thus the result showed that this dosage form requires the addition of antimicrobial preservatives.

The criterion for assessing the effectiveness of antimicrobial preservatives was to determine the logarithm $(\mathrm{lg})$ for reducing the amount of viable cells of bacteria and fungi for the appropriate period of storage after inoculation of gel specimens. In accordance with the requirements of the SPHU, in medicinal products for the application on the skin, the logarithm of reducing the number of viable cells of bacteria in 2 days should be at least 2 , in 7 days should be not less than 3, after 28 days the number of viable cells of bacteria should not increase in comparison with the number of viable microorganisms in the previous control point. The logarithm for reducing the number of viable mushroom cells in 14 days should be at least 2, after 28 days, the number of viable mushroom cells should not increase compared with the number of viable microorganisms in the previous control point.

After inoculation with the microorganisms of the samples under study, mixing was performed to allow uniform distribution of the microorganisms in the sample. Samples were taken from each sample: immediately after seeding and at certain intervals (2, 7,14 and 28 days). To determine the amount of viable microorganisms, the direct sowing method on agarified nutrient media was used on Petri dishes. After receiving the results, the logarithm of reducing the number of viable microorganisms of each culture of the test strain was calculated. The results of the conducted studies to determine the antimicrobial efficacy of nipagin preservatives at various concentrations are given in Tab. 1, 2 . 
Table 1

Antimicrobial effect of $0.1 \%$ nipagin preservative in the gel samples under study

\begin{tabular}{|l|c|c|c|c|c|}
\hline \multirow{2}{*}{ Test culture } & \multirow{2}{*}{$\begin{array}{c}\text { Microbial loading after inocu- } \\
\text { lation, lg CFU/ml }\end{array}$} & \multicolumn{4}{|c|}{ Lg reduction of the initial microbial load (requirements } \\
\cline { 3 - 6 } & of SPHU / sample) & 2 days & 7 days & 14 days & 28 days \\
\hline $\begin{array}{l}\text { Staphylococcus aureus } \\
\text { ATCC 6538 }\end{array}$ & 5.8 & $2 / 2.01$ & $3 / 2.98$ & ND & NI/ND \\
\hline $\begin{array}{l}\text { Pseudomonas aeruginosa } \\
\text { ATCC 9027 }\end{array}$ & 5.9 & $2 / 2.81$ & $3 / 3.1$ & ND & NI/ND \\
\hline $\begin{array}{l}\text { Candida albicans ATCC } \\
\text { 885-653 }\end{array}$ & 5.8 & 3.10 & 3.32 & $2 / \mathrm{ND}$ & NI/ND \\
\hline $\begin{array}{l}\text { Aspergillus brasiliensis } \\
\text { ATCC 16404 }\end{array}$ & 5.7 & 2.81 & 3.62 & $2 / \mathrm{ND}$ & NI/ND \\
\hline
\end{tabular}

Note: $N D$ - microorganisms are not detected; NI-there is no increase in the number of microorganisms

Table 2

Antimicrobial efficacy of nipagin $0.2 \%$ preservative in the gel samples under study

\begin{tabular}{|c|c|c|c|c|c|}
\hline \multirow[t]{2}{*}{ Test culture } & \multirow{2}{*}{$\begin{array}{l}\text { Microbial loading after inocu- } \\
\text { lation, } \lg \mathrm{CFU} / \mathrm{ml}\end{array}$} & \multicolumn{4}{|c|}{$\begin{array}{l}\text { Lg reduction of the initial microbial load (requirements } \\
\text { of SPHU / sample) }\end{array}$} \\
\hline & & 2 days & 7 days & 14 days & 28 days \\
\hline $\begin{array}{l}\text { Staphylococcus aureus } \\
\text { ATCC } 6538\end{array}$ & 5.9 & $2 / 3.32$ & $3 / 4.81$ & ND & NI/ND \\
\hline $\begin{array}{l}\text { Pseudomonas aeruginosa } \\
\text { ATCC } 9027\end{array}$ & 5.8 & $2 / 3.28$ & $3 / 4.66$ & ND & NI/ND \\
\hline $\begin{array}{l}\text { Candida albicans ATCC } \\
885-653\end{array}$ & 5.9 & 3.50 & 4.09 & $2 / \mathrm{ND}$ & NI/ND \\
\hline $\begin{array}{l}\text { Aspergillus brasiliensis } \\
\text { ATCC } 16404\end{array}$ & 5.7 & 3.10 & 4.00 & $2 / \mathrm{ND}$ & NI/ND \\
\hline
\end{tabular}

Note: ND-microorganisms are not detected; NI-there is no increase in the number of microorganisms

The obtained results are shown in Tab. 1 and indicate that in the sample of gel with preservative nipagine $0.1 \%$ after 2 days of storage of inoculated samples, the logarithm of reducing the number of viable microorganisms of bacteria was more than 2.0 (requirements of SPHU) and amounted for Staphylococcus aureus 2.01, for Pseudomonas aeruginosa -2.81 . At the 7 th day of storage of inoculated samples of $0.1 \%$ of preservative nipagin, the study showed that the logarithm of reducing the number of viable microorganisms of bacteria was less than 3.0 (which did not meet the requirements of the SPHU) and amounted to Staphylococcus aureus 2.98, for Pseudomonas aeroginosa -3.1 .

Experimental data of the gel specimens with a concentration of nipagin of $0.2 \%$ (Table 2) showed that after 2 days of storage of inoculated samples, the logarithm of reducing the number of viable microorganisms of bacteria was more than 2.0 (requirements of SPHU) and was for Staphylococcus aureus 3.32, for Pseudomonas aeruginosa -3.28 . At the 7th day of storage of inoculated samples with $0.2 \%$ of preservative nipagine, the study showed that the logarithm of reducing the number of viable microorganisms of bacteria was more than 3.0 (requirements of SPHU) and amounted for Staphylococcus aureus 4.81, for Pseudomonas aeruginosa - 4.66

After 14 days of storage of inoculated samples of viable cells of bacteria, Staphylococcus aureus and Pseudomonas aeruginosa were not detected in gel samples with preservative nipagin of $0.1 \%$ and $0.2 \%$ (requirements of SPHU after 14 days storage of samples of inoculated bacterial microorganisms are not regulated, but a study was conducted). At 28 days (according to the requirements of the SPHU, viable cells should not increase), viable cells of Staphylococcus aureus and Pseudomonas aeruginosa microorganisms for samples with preservative-nipagin were not detected (Table 1,2).

It should be noted that for samples of gels with $0.1 \%$ of preservative nipagin, the logarithm of reducing the number of viable cells of bacteria culture of Staphylococcus aureus in 7 days of storage was 2.98, which does not meet the requirements of SPHU. Therefore, studies conducted with specimens of prescription drug nipagin $0.1 \%$ do not meet the requirements of SPHU in the indicator "antimicrobial effectiveness of preservatives".

As shown in the tab. 2 in the 2 nd and 7 th days of storage of inoculated gel samples with $2.0 \%$ fungi cell cultures, the logarithm for decreasing the number of viable mushroom cells was 3.50 for Candida albicans, respectively 3.10 for the Aspergillus brasiliensis culture (although SPHU for this indicator is not regulated at this time). It has been experimentally established that on the 7 th day of storage this figure was 4.09 and 4.00, respectively (Table 2). On the 14th day of storing inoculated samples of the medicinal product, the logarithm of reducing the number of viable mushroom cells was more than 2.0 (SPHU requirements), and no viable cells were found for Candida albicans fungi cells and Aspergillus brasiliensis culture. After 28 days of storage (as required by SPHU, viable cells should not increase), viable Candida albicans and Aspergillus brasiliensis fungi cells were not detected in the samples (Table 2). Thus, the study of samples of the dosage form with $0.2 \%$ nipagin preservative showed that the specimens 
were fully in accordance with the SPHU requirements for the indicator "antimicrobial efficacy of preservatives" for drugs for the skin.
The results of the study of the effectiveness of antimicrobial preservative of bronopol in the composition of gel $0.2 \%$ are presented in Table 3 .

Table 3

Antimicrobial efficacy of $0.2 \%$ bronopol preservative in gel samples

\begin{tabular}{|l|c|c|c|c|c|}
\hline \multirow{2}{*}{ Test culture } & \multirow{2}{*}{$\begin{array}{c}\text { Microbial loading after inocu- } \\
\text { lation, lg CFU/ml }\end{array}$} & \multicolumn{4}{|c|}{ Lg reduction of the initial microbial load (requirements } \\
\cline { 3 - 6 } & & 2 days & 7 days & 14 days & 28 days \\
\hline $\begin{array}{l}\text { Staphylococcus aureus } \\
\text { ATCC 6538 }\end{array}$ & 5.8 & $2 / 2.30$ & $3 / 2.97$ & 3.48 & NI/ND \\
\hline $\begin{array}{l}\text { Pseudomonas aerugino- } \\
\text { sa } \\
\text { ATCC 9027 }\end{array}$ & 5.8 & $2 / 2.90$ & $3 / 3.52$ & ND & NI/ND \\
\hline $\begin{array}{l}\text { Candida albicans ATCC } \\
885-653\end{array}$ & 5.9 & 1.02 & 1.38 & $2 / 1.41$ & NI/1.92 \\
\hline $\begin{array}{l}\text { Aspergillus brasiliensis } \\
\text { ATCC 16404 }\end{array}$ & 5.7 & - & - & $2 / 0.46$ & NI/0.61 \\
\hline
\end{tabular}

Note: «-» does not diminish; ND - microorganisms are not detected; NI-there is no increase in the number of microorganisms

The results of studies (Table 3) showed the efficacy of samples with preservative of $0.2 \%$ bronopol against infection with Gram negative microflora Pseudomonas aeruginosa ATCC 9027 (the logarithm of decreasing the number of viable cells meets the requirements of SPHU), however, in relation to the grampositive culture of Staphylococcus aureus, ATCC 6538 this figure is not consistent requirements of SPHU. In relation to the cultures of fungi, antimicrobial efficacy in samples with bronopol of $0.2 \%$ was also not detected (Table 3). It has been experimentally proved that samples of the dosage form with preservative bronopol of $0.2 \%$ do not meet the requirements of the SPHU by the indicator "antimicrobial efficacy of preservatives".

The results of experimental studies on the determination of the antimicrobial activity of the preservative of sodium benzoate $0.5 \%$ in the gel indicate that after 2 days of storage of inoculated samples, the logarithm of reducing the number of viable microorganisms of bacteria was more than 2.0 and amounted for Staphylococcus aureus 3.20, for Pseudomonas aeruginosa - 3.03. At the 7 th day of storage of inoculated samples of the drug with sodium benzoate, $0.5 \%$ of the study showed that the logarithm of reducing the number of viable microorganisms of bacteria was more than 3.0 and was for Staphylococcus aureus 4.44, for Pseudomonas aeruginosa - 4.39. After 14 days of storage of inoculated samples of viable cells of bacteria, Staphylococcus aureus and Pseudomonas aeruginosa were not detected (requirements of STP after 14 days storage of samples of inoculated bacterial microorganisms were not regulated, but research was conducted). At day 28 (according to SPHU, viable cells should not increase), viable cells of Staphylococcus aureus and Pseudomonas aeruginosa microorganisms for samples with this preservative - sodium $0.5 \%$ benzoate were not detected.

On the 14th day of storage of inoculated samples of the medicinal product, the logarithm of reducing the number of viable mushroom cells was more than 2.0 (requirements of the SPHU), and no viable cells were found for Candida albicans mushroom cells and Aspergillus brasiliensis culture. After 28 days of storage (according to the requirements of the SPHU, viable cells should not increase) in samples of sodium gels with $0.5 \%$ benzoate, no viable Candida albicans mushroom cells and Aspergillus brasiliensis culture were detected.

Thus, the study of samples of the dosage form with $0.5 \%$ sodium benzoate preservative showed that the specimens meet the requirements of the SPHU in the indicator of "antimicrobial efficacy of preservatives" for drugs for the skin.

\section{Conclusions}

1. The results of experimental studies investigated samples of the gel with preservatives sodium benzoate $0.5 \%$ and $0.2 \%$ nipagin matching "A" criteria of SPHU requirements for drugs for skin use.

2. The antimicrobial preservative effectiveness gel nipagin $0.2 \%$ was slightly higher (lg reduce the number of viable cells of Staphylococcus aureus ATCC 6538 and amounted 3.32 and 4.81; Pseudomonas aeruginosa ATCC 9027 - 3.28 and 4.66; Candida albicans ATCC 885-653 - 3.50 and 4.09; Aspergillus brasiliensis ATCC $16404-3.10$ and 4.00) (at 2 and 7 days, respectively) and spectrum antimicrobial action wider to facilitate quality gel and developed during storage.

3. For further research we will use as a preservative $0.2 \%$ of nipagin.

\section{References}

1. Akao, T., Yoshino, T., Kobashi, K., Hattori, M. (2002). Evaluation of Salicin as an Antipyretic Prodrug that does not Cause Gastric Injury. Planta Medica, 68 (8), 714-718. doi: http://doi.org/10.1055/s-2002-33792

2. Bisset, N. G. (2004). Herbal Drugs and Phytopharmaceuticals. Stuttgart: Medpharm Scientific Publishers, 534-536.

3. Meier, F. M., Frerix, M., Hermann, W., Müller-Ladner, U. (2013). Current immunotherapy in rheumatoid arthritis. Immunotherapy, 5 (9), 955-974. doi: http://doi.org/10.2217/imt.13.94

4. Klimes, J., Vocelka, M., Sedova, L., Dolezal, T., Mlcoch, T., Petrikova, A., Vlcek, J. (2014). Medical and Productivity Costs of Rheumatoid Arthritis in The Czech Republic: Cost-of-Illness Study Based on Disease Severity. Value in Health Regional Issues, 4, 75-81. doi: http://doi.org/10.1016/j.vhri.2014.07.004 

iv, 2,143

5. Postoi, V. V., Vyshnevska, L. I. (2017). Doslidzhennia z rozrobky skladu heliu dlia likuvannia revmatoidnoho artrytu. Ky-

6. Postoi, V. V., Vyshnevska, L. I. (2018). The marketing research of the Ukrainian market of drugs for the treatment of arthritis. News of Pharmacy, 1 (93), 38-42. doi: http://doi.org/10.24959/nphj.18.2198 RIREH, 536.

7. Derzhavna Farmakopeia Ukrainy (2011). Kharkiv: Derzhavne pidpryiemstvo «Naukovo-ekspertnyi farmakopeinyi tsentr»,

8. Derzhavna Farmakopeia Ukrainy Kharkiv. Vol. 1 (2015). Kharkiv: Derzhavne pidpryiemstvo «Ukrainskyi naukovyi farmakopeinyi tsentr yakosti likarskykh zasobiv», 1128.

9. Mirsonbol, S. Z., Issazadeh, K., Pahlaviani, M., Momeni, N. (2014). Antimicrobial efficacy of the methylparaben and benzoate sodium against selected standard microorganisms, clinical and environmental isolates in vitro. Indian Jornal of Fundamental and Applied Life Sciences, 4 (S4), 363-367.

10. Stanojevic, D. C. (2009). Antimicrobial effects of Sodium benzoate, Soium nitrate and Potassium sorbate and Their synergistic action in vitro. Bulgarian Journal of Agricultural Science, 15 (4), 307-311.

Дата надходження рукопису 23.10.2018

Liliia Vyshnevska, Doctor of Pharmaceutical Sciences, Professor, Department of Pharmaceutical Technology of Drugs, National University of Pharmacy, Pushkinska str., 53, Kharkiv, Ukraine, 61002

E-mail: liliiavyshnevska@gmail.com

Oksana Strilets, Doctor of Pharmaceutical Sciences, Professor, Department of Biotechnology, National University of Pharmacy, Pushkinska str., 53, Kharkiv, Ukraine, 61002

E-mail: biotechnology.nuph@gmail.com

Vladyslav Postoy, Postgraduate Student, Department of Pharmaceutical Technology of Drugs, National University of Pharmacy, Pushkinska str., 53, Kharkiv, Ukraine, 61002

E-mail: 19_vladik_91@ukr.net

UDC 615.284:616.995.132:616.995.121:615.076

DOI: 10.15587/2519-4852.2018.151428

\title{
STUDY OF ANTHELMINTIC ACTIVITY AND ACUTE TOXICITY OF MEDICINE OF COMBINED COMPOSITION
}

\author{
(C) K. Semchenko, L. Vyshnevska, N. Polovko
}

Мета. Метою роботи є вивчення антигельмінтної активності та гострої токсичності препарату, щзо містить альбендазол та празиквантел у співвідношенні (1: 4) щзодо збудників аскаридозу у свиней, токсокарозу та дипілідіозу у собак. Ці патогени належать до класу нематодозів (аскаридозу, токсокороз) та изестодозів (дипілідіозу).

Матеріали та методи. Дослідження проводили у копроскопічній лабораторії кафедри паразитологї ХДЗВА за стандартизованим методом Фюллеборна $i$ «Способом кількісного визначення яєць гельмінтів» (патент № 9265). Зразки для дослідження на собаках були отримані в КП "Центр поводження з тваринами". Для вивчення ступеня токсичності запропонованої комбіначії альбендазолу і празиквантелу у поросят відбирали проби крові перед прийомом препарату та через 24 год і 72 год після початку лікування для проведення морфологічних і біохімічних досліджень.

Результати. Отримані результати свідчать про наявність антигельмінтної активності досліджуваного препарату по відношенню до збудників аскаридозу, токсокарозу та дипілідіозу. Показники гематологічних досліджень у свиней вільних від кишкових гельмінтів до та через 24 i 72 год після прийому препарату знаходились у межах фізіологічної норми. Результати клінічного обстеження тварин обох дослідних груп показали, щуо поведінка тварин не змінилася (природня), прийом корму $і$ води в нормі, видимі слизові оболонки - блідо-рожевого кольору, шкірний покрив - иілісний, без пошкоджень, икіра еластична.

Висновки. Таким чином, запропонований препарат демонструє високий рівень антигельмінтної активності щзодо збудників аскаридозу, токсокарозу та дипілідіозу. Ступінь його токсичності відповідає показнику «малотоксичний». Отримані результати вказують на дочільність подальших досліджень Ключові слова: антигельмінтні препарати, альбендазол, празиквантел, нематодоз, цестодоз, фармакологічні дослідження 